\title{
Prevention of Pre-Eclampsia and Eclampsia. A Systematic Review
}

\author{
Sabiha Khanum ${ }^{1,2^{*}}$, Najma Naz ${ }^{3}$, Maria de Lourdes de Souza ${ }^{4}$ \\ ${ }^{1}$ Postgraduate Program in Nursing, Federal University of Santa Catarina, Florianópolis, Brazil \\ ${ }^{2}$ Farkhanda Institute of Nursing (FIN), Gandhara University, Peshawar, Pakistan \\ ${ }^{3}$ Postgraduate College of Nursing (PGCN), Phase-V, Hayatabad, Peshawar, Pakistan \\ ${ }^{4}$ Postgraduate Program in Nursing, REPENSUL Institute, Federal University of Santa Catarina, Florianópolis, Brazil \\ Email: *sabiha.khanum@hotmail.com
}

How to cite this paper: Khanum, S., Naz, N. and de Lourdes de Souza, M. (2018) Prevention of Pre-Eclampsia and Eclampsia. A Systematic Review. Open Journal of Nursing, 8, 26-44.

https://doi.org/10.4236/ojn.2018.81003

Received: December 25, 2017

Accepted: January 22, 2018

Published: January 25, 2018

Copyright $\odot 2018$ by authors and Scientific Research Publishing Inc. This work is licensed under the Creative Commons Attribution International License (CC BY 4.0).

http://creativecommons.org/licenses/by/4.0/ Open Access

\begin{abstract}
Every pregnant woman needs continuous, timely and supportive care throughout during pregnancy for safe motherhood. The objective of this study was to analyze and evaluate the available medications and techniques for the prevention and treatment of pre-eclampsia and eclampsia. The standard methodology of systematic review without meta-analysis was followed and only RCTs and systematic reviews were included in the review. Three electronic data sources (PubMed/Medline, CINAHL, and Cochrane) were searched for studies, published between 1986 and 2016 on the prevention and control of pre-eclampsia and eclampsia. 47 studies were finally included in the review, of which 18 were systematic reviews and 29 were RCTs. Technologies and techniques used in the included studies for the prevention and control of pre-eclampsia and eclampsia are Magnesium Sulphate, Aspirin, Antioxidant (Vitamin C, E and Lycopene), Calcium supplementation, Chinese Herbal Medicine, physical activities, Nitric Oxide, Marine Food Oils, Low Salt Diet, Garlic, Plasma Volume Expansion, Low-dose Dopamine, Progesterone, Smoking, and Diuretics. Magnesium sulfate appears to be the most effective treatment which reduces the risk of eclampsia by more than $50 \%$. However, its best dose and route are still controversial and need further research. The knowledge and experience of nurses in properly using the protocols and evidence-based interventions are necessary for the wellbeing of pregnant women.
\end{abstract}

\section{Keywords}

Pre-Eclampsia, Eclampsia, Maternal Mortality, Women's Health, Pregnancy 


\section{Background}

Pregnant women require continuous, prompt and supportive care throughout their pregnancies as well as after childbirth for safe motherhood.

Pre-eclampsia, one of the major complications during gestation, is a hypertensive disorder and a serious condition that occurs typically after 20 weeks of pregnancy. It is a combination of hypertension (raised blood pressure) and proteinuria (the presence of protein in the urine) [1]. Most women with preeclampsia give birth without problems because of the prompt and adequate health care services they receive. However, severe pre-eclampsia can cause problems such as stroke, kidney failure, liver failure, and blood clotting [1]. The generally accepted criteria for identifying pre-eclampsia is a persistent diastolic blood pressure greater than $90 \mathrm{~mm} \mathrm{Hg}$ with the occurrence of proteinuria greater than or equal to 0.3 grams in a 24 -hour urine specimen [2].

The pathogenesis of pre-eclampsia is not clearly understood [2]. Experts believe it begins with a disturbance in the placenta, followed by insufficient blood flow to the uterus resulting in inflammation and progressive endothelial damage [2]. Obesity, chronic hypertension, diabetes, multiple pregnancies, first pregnancy, adolescent pregnancy and history of pre-eclampsia are among the risk factors for pre-eclampsia [2].

On the other hand, eclampsia, which is usually rare but potentially life-threatening, is characterized by the occurrence of a seizure in association with pre-eclampsia, swelling feet, sudden weight gain, headaches, and changes in vision. Approximately 1 out every 200 women who had pre-eclampsia, eventually develop a more serious condition of eclampsia which causes about 50,000 maternal deaths each year [3].

Globally, about 300,000 women die each year from complications of pregnancy and more than $95 \%$ of these women are in Africa and Asia [4]. Preeclampsia and eclampsia together affect about $10 \%$ of all pregnant women around the world [5] [6]. In Africa and Asia, about one-tenth of all maternal deaths and in Latin America one-quarter of all maternal deaths are associated with hypertensive disorders of pregnancy. More than half of the maternal deaths occur in sub-Saharan Africa and about one third occur in South Asia [4]. Among the hypertensive disorders of pregnancy, pre-eclampsia and eclampsia remain one of the major causes of maternal mortality [4] [7]. An estimated $4 \%$ to $10 \%$ of pregnant women in Australia develop pre-eclampsia, causing about five maternal deaths and up to 300 to 500 perinatal deaths per year [8].

\section{Objectives}

- To analyze and evaluate the available techniques and medication used in past 30 years for the prevention and control of pre-eclampsia and eclampsia, with the motive to reduce the maternal mortality.

- To describe and evaluate these techniques and medication, their benefits and their adverse effects and their role in the prevention and control of pre-eclampsia and eclampsia in pregnant women. 
- To enhance understanding of these techniques and medication and their relationship with pre-eclampsia and eclampsia, which eventually will contribute to the development of more preventive strategies and lower mortality rate.

\section{Materials and Methods}

\subsection{Design}

PRISMA guidelines [9] were used as a basis for the overall study approach. A systematic search was conducted from January 2016 to January 2017, to answer the research question of: What are the available best technologies and techniques for the prevention and control of pre-eclampsia and eclampsia? PubMed/MEDLINE, CINAHL, and Cochrane were searched for articles published between 1986 to 2016, reporting on the available technologies and techniques for the prevention and control of pre-eclampsia and eclampsia in pregnant women. The question was adjusted according to the PICO acronyms; P (population/participants) representing pregnant women with hypertension, pre-eclampsia or eclampsia; I (intervention) represent the use of available technologies and techniques; $\mathrm{C}$ shows comparison in the control group, the placebo group or non-existence of the comparison group; and $\mathbf{O}$ represented the outcomes of interest which were prevention and control of pre-eclampsia and eclampsia and reduction in maternal mortality. The search strategy was based on a number of medical subject headings MESH terms and text words, summarized in Table 1.

\subsection{Inclusion Criteria}

Systematic Reviews and RCTs published in the English language between 1986 to 2016 based on the prevention and control of pre-eclampsia and eclampsia were eligible for inclusion in this review.

\subsection{Exclusion Criteria}

Studies, except systematic reviews and RCT's, were excluded. Studies not published in the English language, or whose topics were irrelevant to the objective of this study were also excluded.

Table 1. Database, Filters and Keywords.

\begin{tabular}{cll}
\hline Database & & \multicolumn{1}{c}{ Filters } \\
\hline & Text: Complete; & Keywords \\
& Publication Date: 01-01-1986 to 31-12-2016; & ("Eclampsia/prevention and control” [Mesh]) \\
PUBMED & Language: English; & OR "PreEclamsia/prevention and Control” [Mesh] \\
& Sex: Female; & Prevention and control of preeclampsia or eclampsia \\
COCHRANE & Total review 1085, Complete review 179 & \\
& Text: Complete; & Prevention and control of preeclampsia or eclampsia \\
& Publication Date: 01-01-1986 to 31-12-2016; & \\
& Language: English; &
\end{tabular}




\subsection{Search Outcome}

A total of 1808 articles were initially identified using the search criteria from all the three databases, of which 14 were in duplicate. Titles screening of the remaining 1794 articles resulted in 330 relevant articles being selected for abstract screening. The abstracts of these 330 papers were then examined resulting in 58 papers being examined in full. Of these, 11 were excluded after quality assessment. The remaining 47 studies were fully read and were included in the review as shown in Figure 1.

Each article was screened by two independent reviewers and disagreement between them was resolved by discussion. The aim was to identify as many articles as possible which have reported the use of different techniques and technologies for the prevention of pre-eclampsia and eclampsia in past 30 years.

\subsection{Quality Appraisal}

We assessed the quality of each paper meeting the inclusion criteria using the following: 1) relevance to the systematic review 2) validity and appropriateness of methodology 3) quality of evidence generalizability of results 4) quality of reporting

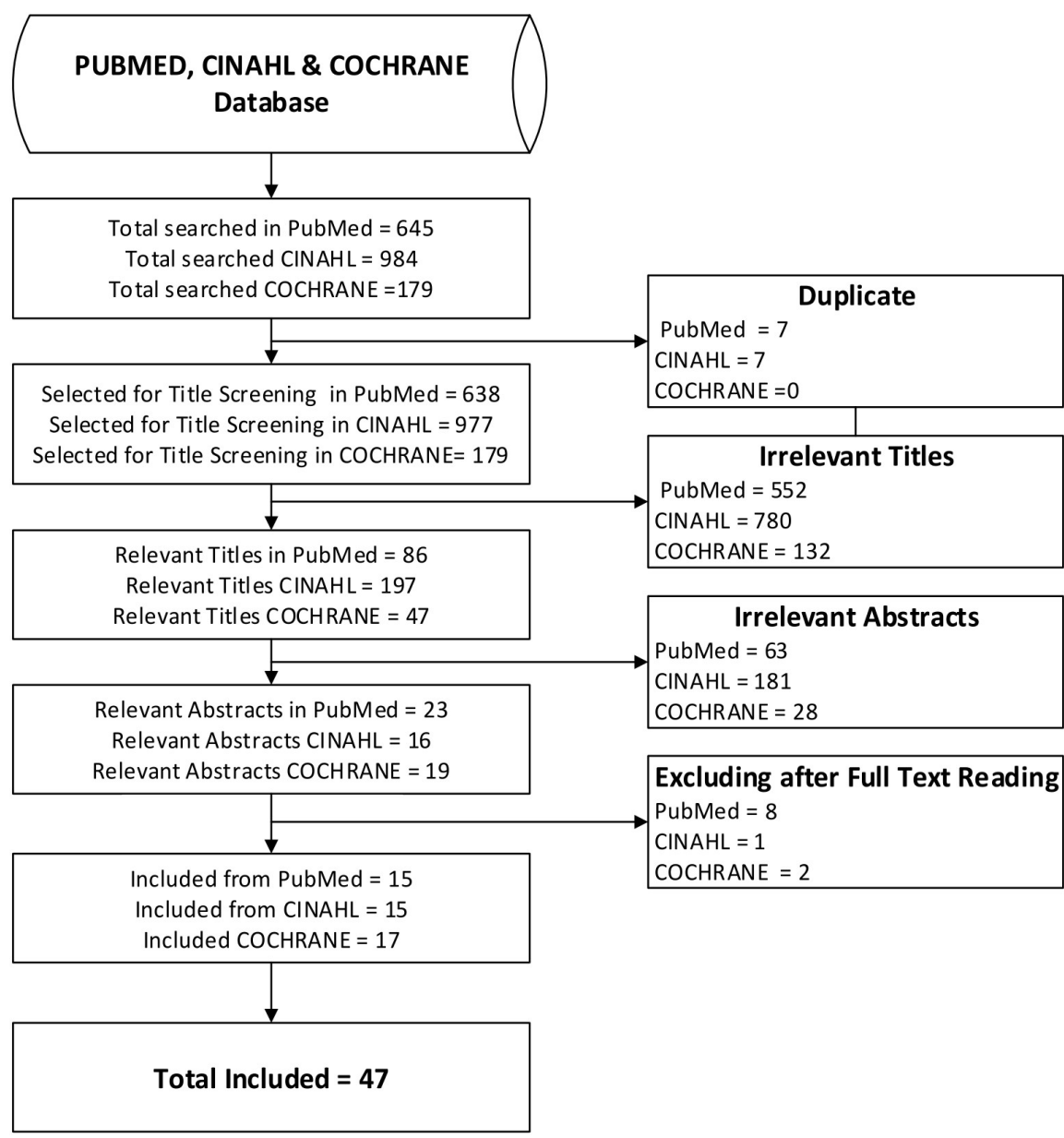

Figure 1. Flow diagram showing the process of identification and screening for this systematic review. 
5) limitations of the study and how it was adjusted. The quality of the outcome was assessed using the Evidence Level: Joanna Briggs from Level I to II as outlined in Table 2.

\subsection{Data Extraction and Synthesis}

All 47 papers were independently assessed by two reviewers. The following information was extracted from the included studies. General information about authors, journal, publication date, country, research design, location, participants, aim, sample size, Evidence of use of the available technologies and techniques in pregnant women for the prevention of pre-eclampsia or eclampsia, results and descriptive summaries of numerical data. Synthesis of the studies involved categorizing technologies and techniques by their characteristics, narrating and summarizing its effectiveness and presenting data visually.

\section{Result and Discussion}

Among the 47 articles included in this study, 18 were systematic reviews, 29 were RCTs, including 9 multicenter RCTs. All the identified articles for systematic review were based on quantitative research studies. All included studies in this systematic review, restricted sampled participants to nulliparous or multiparous pregnant women (between 12 and 34 weeks of gestation), with hypertension, preeclampsia or eclampsia. Age of the participants varies between 14 to 45 years and sample size of the selected studies varies from 30 in [10] to 37,560 in [11] participants.

The included 29 RCTs were conducted and based in countries; $\mathrm{UK}=3$, Italy = 1 , Brazil $=1$, Iran $=1$, South Africa $=2$, Barbados $=1$, India $=2$, Finland $=2$, $\mathrm{USA}=4$, Mexico $=1$, Japan $=1$, Australia $=1$. Similarly, the multicenter studies were conducted in countries; 1 Multicenter RCT in South Africa, Turkey, Brazil, Argentina, Philippine, Dominican, America; 1 Multicenter RCT in France and Belgium; 1 Multicenter RCT in America and Europe; 1 Multicenter RCT in India, Peru, South Africa, Vietnam; 1 Multicenter RCT in Argentina, Brazil, Colombia, Ghana, India, Uganda, Venezuela, Zimbabwe; 1 Multicenter RCT in England, Ireland, Scotland; 1 Multicenter RCT in Peru, Argentina, India, Egypt, South Africa, UK; 1 Multicenter RCT in Australian and New Zeeland; 1 Multicenter RCT in Canada and Mexico.

Table 2. Level of Evidence. Reproduced from: The Joanna Briggs Institute for Evidence Based Nursing and Midwifery (2002).

\begin{tabular}{cl}
\hline Level & \multicolumn{1}{c}{ Description } \\
\hline I & Evidence obtained from a systematic review of all relevant randomized controlled trials. \\
II & Evidence obtained from at least one properly deigned randomized controlled trial. \\
III.1 & Evidence obtained from well-designed controlled trials, not randomized. \\
III.2 & Evidence obtained from comparative studies such as cohort studies, case control studies preferably from more than one center or research group. \\
III.3 & Evidence obtained from multiple time series with or without the intervention. Dramatic results in uncontrolled experiments. \\
IV & Evidence from opinion of respected authorities, based on clinical experience, descriptive studies, or reports of expert committees. \\
\hline
\end{tabular}


The included studies used different intervention for the prevention and treatment of pre-eclampsia, eclampsia and its complications in pregnant women. These medications include Magnisium Sulphate (8 studies), Aspirin (9 studies), Antioxidant including Vitamin C and E (9 studies), Calcium Supplementation (4 studies), Physical Activity and Exercise (3 studies), Nitric Oxide (3 studies), Marine Food Oils (2 studies), Low Salt Diet (1 studies), Garlic (1 studies), Chinese Herbal Medicine (1 studies), Plasma Volume Expansion (1 studies), Lowdose Dopamine (1 studies), Progesterone (1 studies), Antioxidant Lycopene (1 studies), Smoking (1 studies) and Diuretics (1 studies). A detail discussion on these medications is presented in section 4 while their summarized results are provided from Tables 3-8. In tables, SR represents systematic review, RCT represents randomized control trial, $\mathrm{MgSo} 4$ represents magnesium sulfate, PC means placebo-controlled and DB represents double blinded.

The review identifies a central and supportive role of magnesium sulfate in the prevention of pre-eclampsia and eclampsia in pregnant women [12] [13] [14]. Although, there is little evidence about the size of the effective dose, in order to draw any firm conclusions. Technologies and techniques including Magnesium sulfate and many others identified in this study used for the prevention of pre-eclampsia and eclampsia are discussed in detail, as follows.

\subsection{Magnesium Sulfate}

It is generally believed that anticonvulsant is effective in managing eclampsia and that why magnesium sulfate, the most commonly used anticonvulsants, is considered a treatment of choice for eclampsia [14] [15]. Table 3 shows the summary of magnesium sulfate related studies included in this systematic review.

Magnesium sulfate is the most effective treatment which reduces the risk of eclampsia by more than $50 \%$, as concluded by a systematic review [14] with 15 trials and more than 12,000 women. Similarly, magnesium sulfate is also effective in reducing the incidence of eclampsia in women with severe pre-eclampsia [16]. Magnesium sulfate performs better than a lytic cocktail [13] and is more effective than nimodipine [12] in preventing maternal death, further seizures and other serious maternal morbidity in pregnant women with eclampsia.

Magnesium sulfate had a $52 \%$ lower risk of recurrent convulsions (95\% CI $64 \%$ to $37 \%$ reduction) than that allocated diazepam (60 (13.2\%) vs 126 (27.9\%). Similarly, Magnesium sulfate had a $67 \%$ lower risk of recurrent convulsions ( $95 \%$ CI $79 \%$ to $47 \%$ reduction) than that allocated phenytoin ( 22 (5.7\%) vs 66 (17.1\%) [17]. Low dose i.v. magnesium sulfate regimen is equally effective in the prevention of convulsion recurrence and maternal deaths in eclamptic women compared with an i.m. magnesium sulfate regimen [18].

Despite the strong evidence in favor of magnesium sulfate for prevention of eclampsia, trials comparing alternative techniques regimens are too small for a reliable conclusion. There was not enough evidence to show what the best dose of magnesium sulfate is for women with pre-eclampsia or eclampsia, and what its best route is. Magnesium sulfate has also been associated with increased risk of 
Table 3. Summary of magnesium sulphate related studies.

\begin{tabular}{|c|c|c|c|c|c|}
\hline Ref. & Study Type & Intervention & $\begin{array}{l}\text { Population/Sample } \\
\text { Size }\end{array}$ & Results/Benefits & Adverse Effects \\
\hline$[12]$ & $\begin{array}{l}\text { Unblinded } \\
\text { Multicenter Trial }\end{array}$ & $\begin{array}{l}\text { Nimodipine }(60 \mathrm{mg} / 4 \mathrm{~h} \\
\text { orally) and IV MgSO } 4 \\
\text { of } 2 \mathrm{~g} / \mathrm{h} \text { and } 1 \mathrm{~g} / \mathrm{h}\end{array}$ & $\begin{array}{l}1650 \text { women with } \\
\text { severe pre-eclampsia }\end{array}$ & $\begin{array}{l}\text { MgSo } 4 \text { is more effective and has lower } \\
\text { mortality rate than Nimodipine in women } \\
\text { with severe pre-eclampsia }\end{array}$ & $\begin{array}{l}\text { Increases the } \\
\text { risk of } \mathrm{PPH} \\
\text { and respiratory } \\
\text { difficulty }\end{array}$ \\
\hline$[17]$ & Multicenter RCT & $\begin{array}{l}\text { MgSo4 Versus } \\
\text { Diazepam Versus } \\
\text { Phenytoin }\end{array}$ & $\begin{array}{l}1680 \text { women with } \\
\text { eclampsia from } 9 \\
\text { countries }\end{array}$ & $\begin{array}{l}\text { MgSo } 4 \text { has } 52 \%(95 \% \mathrm{CI}) \text { and } 67 \%(95 \% \mathrm{CI}) \\
\text { lower risk of recurrent convulsions than } \\
\text { diazepam and phenytoin respectively }\end{array}$ & Not Reported \\
\hline$[18]$ & Prospective Trial & $\begin{array}{l}4 \mathrm{~g} \text { IV MgSO } 4 \text { followed } \\
\text { by i.m. injections or IV } \\
0.6 \mathrm{~g} / \mathrm{h}\end{array}$ & $\begin{array}{l}630 \text { women with } \\
\text { eclampsia }\end{array}$ & $\begin{array}{l}\text { Both interventions are equally effective in } \\
\text { the prevention of convulsion recurrence } \\
\text { and maternal deaths }\end{array}$ & Not Reported \\
\hline$[16]$ & $\mathrm{RCT}$ & $\begin{array}{l}\text { IV magnesium sulphate } \\
\text { ( } 4 \mathrm{~g}) \text { versus Placebo }\end{array}$ & $\begin{array}{l}685 \text { Women with } \\
\text { Severe pre-eclampsia }\end{array}$ & $\begin{array}{l}\text { IV MgSo } 4 \text { is effective in reducing the } \\
\text { incidence of severe pre-eclampsia }\end{array}$ & Not Reported \\
\hline$[26]$ & $\mathrm{RCT}$ & $\begin{array}{l}\text { IV MgSo } 4(6 \mathrm{~g}) \\
\text { followed by } 2 \mathrm{~g} / \mathrm{h}\end{array}$ & $\begin{array}{l}222 \text { Women with } \\
\text { mild pre-eclampsia }\end{array}$ & $\begin{array}{l}\text { No major impact on disease progression. Does } \\
\text { not seem to increase rates of cesarean delivery, } \\
\text { infectious morbidity, obstetric hemorrhage. }\end{array}$ & Not Reported \\
\hline$[27]$ & SR & $\begin{array}{l}\text { MgSo4 with different } \\
\text { dose }\end{array}$ & $\begin{array}{l}6 \text { RCTs with } 866 \\
\text { women }\end{array}$ & $\begin{array}{l}\text { Strong evidence in favour of MgSo } 4 \text {. Lack of } \\
\text { clarity for best dose size/route }\end{array}$ & Not Reported \\
\hline$[13]$ & SR & $\begin{array}{l}\text { MgSo } 4 \text { Compared With } \\
\text { Lytic Cocktail }\end{array}$ & $\begin{array}{l}3 \text { small trials } \\
\text { involving } 397 \text { women }\end{array}$ & $\begin{array}{l}\text { MgSo4 is more effective in reducing MM and } \\
\text { serious maternal morbidity than Lytic cocktail. }\end{array}$ & $\begin{array}{l}\text { Recurrence of } \\
\text { seizures. }\end{array}$ \\
\hline$[14]$ & SR & $\begin{array}{l}\text { MgSO } 4 \text { and Other } \\
\text { Anticonvulsants }\end{array}$ & $\begin{array}{l}15 \text { RCTs with more } \\
\text { than } 12000 \text { women }\end{array}$ & $\begin{array}{l}\text { MgSo } 4 \text { reduce the risk of eclampsia by } 50 \% \\
(95 \% \mathrm{CI}) \text { and is more effective than phenytoin, } \\
\text { diazepam or nimodipine }\end{array}$ & Flushing \\
\hline
\end{tabular}

PPH and respiratory difficulties [12], flushing [14] and overdose adverse effects (primarily from medication and administration errors) and may increase the rates of cesarean delivery [19].

\subsection{Aspirin}

Antiplatelet agents, in particular, Aspirin, are among the most promising candidates for prevention of pre-eclampsia. They keep a good balance between prostacyclin, a vasodilator, and thromboxane, a vasoconstrictor, and stimulant of platelet aggregation [20]. However, according to the studies included in this review, Aspirin does not show any significant benefits in the incidence of proteinuric pre-eclampsia, preterm delivery, birthweight or of stillbirth, placental abruption, and neonatal death [21] [22] [23] [24] [25].

Although, a meta-analysis suggested that low-dose aspirin initiated before 16 weeks of gestation reduces the risk of pre-eclampsia (RR 0.6, 95\% CI $0.4-0.8$ ) and severe pre-eclampsia (RR 0.3 , 95\% CI 0.1 - 0.7) [20]. Similarly, the results obtained in another review [11] shows that antiplatelet agents, mostly low-dose aspirin, have moderate benefits (up to $17 \%$ reduction in the risk of pre-eclampsia (RR 0.83, 95\% CI 0.77 to 0.89) [11], when used for prevention of pre-eclampsia and its complications. The role of aspirin in the prevention of pre-eclampsia continues to be debatable and unclear. Its benefits and effectiveness are from small to moderate depending on the outcome. Table 4 shows the summary of Aspirin-related studies included in this review. 
Table 4. Summary of Aspirin-related studies included in this review.

\begin{tabular}{|c|c|c|c|c|c|}
\hline Ref. & $\begin{array}{c}\text { Study } \\
\text { Type/Acronym }\end{array}$ & Intervention & Population/Sample Size & Results/Benefits & Adverse Effects \\
\hline [21] & $\begin{array}{l}\text { Randomized PC } \\
\text { Trial/ (BLASP) }\end{array}$ & $\begin{array}{l}75 \mathrm{mg} \\
\text { controlled-release } \\
\text { Aspirin }\end{array}$ & $\begin{array}{l}3647 \text { women (12 - } 32 \text { week } \\
\text { pregnancy) }\end{array}$ & $\begin{array}{l}\text { Do not support the routine use of } \\
\text { low-dose aspirin for prevention of } \\
\text { pre-eclampsia or its complications. }\end{array}$ & Not Reported \\
\hline [20] & $\begin{array}{l}\text { Randomized DB } \\
\text { PC Trial }\end{array}$ & $\begin{array}{l}100 \mathrm{mg} \text { low-dose } \\
\text { Aspirin per day }\end{array}$ & $\begin{array}{l}152 \text { women (>12 week } \\
\text { pregnancy) }\end{array}$ & $\begin{array}{l}\text { Showed no statistically significant effect } \\
\text { of aspirin in preventing pre-eclampsia }\end{array}$ & Not Reported \\
\hline [22] & $\begin{array}{l}\text { Randomized DB } \\
\text { PC Trial }\end{array}$ & $\begin{array}{l}100 \mathrm{mg} \text { low-dose } \\
\text { Aspirin per day }\end{array}$ & 487 Women & $\begin{array}{l}\text { No statistical difference between low-dose } \\
\text { aspirin and placebo groups }\end{array}$ & Not Reported \\
\hline [28] & Randomized Trial & $\begin{array}{l}100 \mathrm{mg} \text { low-dose } \\
\text { Aspirin per day }\end{array}$ & $\begin{array}{l}40 \text { women }(<14 \text { week } \\
\text { pregnancy) }\end{array}$ & $\begin{array}{l}\text { Limited data show some support }(31.3 \% \\
\text { vs } 36.8 \% \text { ) for early treatment with } \\
\text { Aspirin in pregnant women }\end{array}$ & Not Reported \\
\hline [29] & $\mathrm{RCT}$ & $\begin{array}{l}60 \mathrm{mg} \text { Aspirin } \\
\text { per day }\end{array}$ & $\begin{array}{l}3135 \text { nulliparous women } \\
\text { (13 - } 26 \text { week pregnancy) }\end{array}$ & $\begin{array}{l}\text { Low-dose aspirin decreases the incidence } \\
\text { of pre-eclampsia in nulliparous women; } \\
4.6 \% \text { in the aspirin group and } 6.3 \% \text { in the } \\
\text { placebo group (RR, } 0.7 ; 95 \% \text { CI, } 0.6 \text { to } 1.0 \text {; } \\
P=0.05 \text { ) }\end{array}$ & $\begin{array}{l}\text { Increases the risk of } \\
\text { abruption placentae }\end{array}$ \\
\hline [23] & $\begin{array}{l}\text { Randomized DB } \\
\text { PC Trial }\end{array}$ & $\begin{array}{l}100 \mathrm{mg} \text { low-dose } \\
\text { Aspirin per day }\end{array}$ & $\begin{array}{l}3294 \text { women ( } 14 \text { - } 20 \text { week } \\
\text { pregnancy) }\end{array}$ & $\begin{array}{l}\text { Does not reduce the incidence of } \\
\text { pre-eclampsia in nulliparous women }\end{array}$ & $\begin{array}{l}\text { increase in bleeding } \\
\text { complications }\end{array}$ \\
\hline [24] & RCT & $\begin{array}{l}150 \mathrm{mg} \text { low-dose } \\
\text { Aspirin per day }\end{array}$ & $\begin{array}{l}560 \text { Women ( } 22 \text { - } 24 \text { week } \\
\text { pregnancy) }\end{array}$ & $\begin{array}{l}\text { No significant differences between the } \\
\text { aspirin and placebo groups }\end{array}$ & Not Reported \\
\hline [25] & $\begin{array}{l}\text { Randomized DB } \\
\text { PC Trial }\end{array}$ & $\begin{array}{l}60 \mathrm{mg} \text { Aspirin } \\
\text { per day }\end{array}$ & $\begin{array}{l}2503 \text { women (13 - } 26 \text { week } \\
\text { pregnancy) }\end{array}$ & $\begin{array}{l}\text { Low-dose aspirin did not reduce the } \\
\text { incidence of pre-eclampsia significantly } \\
\text { or improve perinatal outcomes in } \\
\text { pregnant women. }\end{array}$ & Not Reported \\
\hline [11] & SR & $\begin{array}{l}\text { Antiplatelet } \\
\text { Agents (low-dose } \\
\text { aspirin) }\end{array}$ & 59 trials with 37,560 women & $\begin{array}{l}\text { Antiplatelet Agents, largely low-dose } \\
\text { aspirin reduce the risk of pre-eclampsia } \\
\text { by } 17 \% \text { (RR } 0.83,95 \% \text { CI } 0.77 \text { to } 0.89 \text { ) }\end{array}$ & Not Reported \\
\hline
\end{tabular}

\subsection{Antioxidant, Vitamin C and E}

There are several pieces of evidence which support the hypothesis that oxidative stress, an imbalance between pro-oxidant and antioxidant forces, plays a key role in the development of pre-eclampsia during pregnancy [30]. However, according to the results of this review, no promising results have yet been shown by antioxidants including vitamin $\mathrm{C}$ and $\mathrm{E}$ in reducing the complications of pre-eclampsia or eclampsia. Table 5 shows the summary of antioxidants related studies included in this systematic review.

Results obtained in [30]-[38] fails to demonstrate the benefits of antioxidant supplementation in reducing the rate of pre-eclampsia and hence do not encourage its routine use against pre-eclampsia. Previous research also does not support the use of vitamin $\mathrm{C}$ and $\mathrm{E}$ supplementation in pregnancy to reduce the risk of pre-eclampsia or its complications [37]. However, the possibility that vitamin supplementation might be beneficial in women with a low antioxidant status at baseline needs further research and trials. 
Table 5. Summary of Antioxidant and Vitamin C, E related studies.

\begin{tabular}{|c|c|c|c|c|c|}
\hline Ref. & $\begin{array}{c}\text { Study } \\
\text { Type/Acronym }\end{array}$ & Intervention & $\begin{array}{l}\text { Population/Sample } \\
\text { Size }\end{array}$ & Results/Benefits & Adverse Effects \\
\hline [31] & $\begin{array}{l}\text { Randomized DB } \\
\text { PC Trial }\end{array}$ & $\begin{array}{l}\text { (800IU Vitamin E, } 1 \mathrm{~g} \text { Vitamin } \\
\mathrm{C} \text { and } 200 \mathrm{~g} \text { allopurinol) daily }\end{array}$ & $\begin{array}{l}54 \text { women with severe } \\
\text { pre-eclampsia ( } 24 \text { - } 32 \\
\text { weeks pregnancy) }\end{array}$ & $\begin{array}{l}\text { Do not encourage the routine use of } \\
\text { antioxidants against pre-eclampsia }\end{array}$ & $\begin{array}{l}\text { Increase in acne, } \\
\text { transient weakness } \\
\text { and skin rash }\end{array}$ \\
\hline [30] & $\begin{array}{l}\text { Multicenter } \\
\text { RCT/(INTAPP) }\end{array}$ & $\begin{array}{l}\text { 1g vitamin C and } 400 \text { IU of } \\
\text { Vitamin E or placebo daily }\end{array}$ & $\begin{array}{l}2647 \text { women from } 27 \\
\text { centers }\end{array}$ & $\begin{array}{l}\text { No reduction in the rate of } \\
\text { pre-eclampsia }\end{array}$ & $\begin{array}{l}\text { increased fetal loss } \\
\text { and preterm } \\
\text { rupture of } \\
\text { membrane }\end{array}$ \\
\hline [32] & $\begin{array}{l}\text { Multicenter PC } \\
\text { Trial }\end{array}$ & $\begin{array}{l}\text { 1g vitamin C and } 400 \text { IU of } \\
\text { Vitamin E or placebo daily }\end{array}$ & $\begin{array}{l}687 \text { women }(14-22 \\
\text { weeks pregnancy) }\end{array}$ & $\begin{array}{l}\text { No reduction in the rate of } \\
\text { pre-eclampsia high-risk pregnant } \\
\text { women with low nutritional status }\end{array}$ & Not Reported \\
\hline [33] & SR & $\begin{array}{l}\text { Antioxidant (with Vitamin C, } \\
\text { E, selenium and lycopene) }\end{array}$ & $\begin{array}{l}10 \text { RCT with } 6533 \\
\text { women (12 - } 28 \text { weeks } \\
\text { pregnancy) }\end{array}$ & $\begin{array}{l}\text { No reduction in the risk of } \\
\text { pre-eclampsia and its complications }\end{array}$ & Not Reported \\
\hline [34] & $\begin{array}{l}\text { Multicenter PC } \\
\text { Trial/ (DAPIT) }\end{array}$ & $\begin{array}{l}1 \mathrm{~g} \text { vitamin } \mathrm{C} \text { and } 400 \mathrm{IU} \text { of } \\
\text { Vitamin } \mathrm{E} \text { or placebo }\end{array}$ & $\begin{array}{l}762 \text { diabetic pregnant } \\
\text { women }(8-22 \text { weeks })\end{array}$ & $\begin{array}{l}\text { No reduction in the risk of } \\
\text { pre-eclampsia in women with } \\
\text { type } 1 \text { diabetes }\end{array}$ & Not Reported \\
\hline [35] & $\begin{array}{l}\text { Multicenter PC } \\
\text { Trial }\end{array}$ & $\begin{array}{l}1 \mathrm{~g} \text { vitamin } \mathrm{C} \text { and } 400 \mathrm{IU} \text { of } \\
\text { Vitamin E or placebo daily }\end{array}$ & $\begin{array}{l}1877 \text { women from two } \\
\text { countries ( } 14-22 \\
\text { weeks pregnancy) }\end{array}$ & $\begin{array}{l}\text { No reduction in the risk of } \\
\text { pre-eclampsia, intrauterine } \\
\text { growth restriction, or other } \\
\text { serious outcomes in their infants. }\end{array}$ & Not Reported \\
\hline [36] & $\begin{array}{l}\text { Randomized PC } \\
\text { Trial }\end{array}$ & $\begin{array}{l}1 \mathrm{~g} \text { vitamin } \mathrm{C} \text { and } 400 \mathrm{IU} \text { of } \\
\text { Vitamin } \mathrm{E} \text { or placebo }\end{array}$ & $\begin{array}{l}2410 \text { Women ( } 14-22 \\
\text { weeks pregnancy) }\end{array}$ & $\begin{array}{l}\text { Does not prevent pre-eclampsia } \\
\text { in women at risk }\end{array}$ & $\begin{array}{l}\text { Increase rate of low } \\
\text { birth-weight babies }\end{array}$ \\
\hline [37] & $\begin{array}{l}\text { Multicenter PC } \\
\text { Trial }\end{array}$ & $\begin{array}{l}1 \mathrm{~g} \text { vitamin } \mathrm{C} \text { and } 400 \mathrm{IU} \text { of } \\
\text { Vitamin } \mathrm{E} \text { or placebo }\end{array}$ & $\begin{array}{l}10,154 \text { Women }(9-16 \\
\text { weeks pregnancy) }\end{array}$ & $\begin{array}{l}\text { No reduction in the rate of adverse } \\
\text { maternal or perinatal outcomes }\end{array}$ & Not Reported \\
\hline [38] & $\begin{array}{l}\text { Randomized DB } \\
\text { PC Trial }\end{array}$ & $\begin{array}{l}1 \mathrm{~g} \text { vitamin } \mathrm{C} \text { and } 400 \mathrm{IU} \\
\text { Vitamin } \mathrm{E} \text { or placebo }\end{array}$ & $\begin{array}{l}739 \text { Women }(12-19 \\
\text { weeks pregnancy) }\end{array}$ & $\begin{array}{l}\text { No benefits in reducing the rate of } \\
\text { pre-eclampsia among patients with } \\
\text { chronic hypertension }\end{array}$ & Not Reported \\
\hline
\end{tabular}

\subsection{Calcium Supplementation}

Historically, a relationship between calcium deficiency and homeostasis and preeclampsia was suggested [39]. In this regard, nutrient supplements consisting of calcium are prescribed to treat deficiencies or for pharmacologic effects during pregnancy. The use of calcium supplementation in the light of this review did not show strong evidence in favor of it routine use [40] [41]. However, a systematic review [42] with 12 good quality RCTs involving 15,528 women and an RCT in [10] show promising results in favor of calcium supplementation in the prevention of pre-eclampsia and related problems. Overall it seems that calcium supplementation appears to reduce the risk of pre-eclampsia and reduce the rare occurrence of the serious morbidity. However, further research is needed in different settings and trials to explain its role in the prevention of pre-eclampsia. Table 6 shows the summary of calcium-related studies included in this systematic review. 
Table 6. Summary of Calcium related studies included in this review.

\begin{tabular}{|c|c|c|c|c|c|}
\hline Ref. & Study Type & Intervention & Population/Sample Size & Results/Benefits & Adverse Effects \\
\hline$[40]$ & Randomized DB PC Trial & $\begin{array}{l}1.5 \mathrm{~g} \text { calcium/day } \\
\text { or placebo }\end{array}$ & $\begin{array}{l}8325 \text { women }<20 \text { week } \\
\text { pregnancy }\end{array}$ & $\begin{array}{l}\text { Did not prevent pre-eclampsia } \\
\text { but did reduce its severity and ma- } \\
\text { ternal morbidity }\end{array}$ & Not Reported \\
\hline$[41]$ & Randomized DB PC Trial & $\begin{array}{l}2 \mathrm{~g} \text { calcium/day or } \\
\text { placebo }\end{array}$ & $\begin{array}{l}4589 \text { women }(13-21 \text { weeks } \\
\text { pregnancy) }\end{array}$ & $\begin{array}{l}\text { No prevention in pre-eclampsia, or } \\
\text { its severity or delay its onset }\end{array}$ & Not Reported \\
\hline$[42]$ & Systematic Review & $\begin{array}{l}1.5 \mathrm{~g} \text { to } 2 \mathrm{~g} \text { cal- } \\
\text { cium/day }\end{array}$ & 12 RCTs with 15,528 women & $\begin{array}{l}\text { Appears to reduce the risk of } \\
\text { pre-eclampsia and serious morbidity }\end{array}$ & $\begin{array}{l}\text { No other clear } \\
\text { benefit or harms }\end{array}$ \\
\hline$[10]$ & Randomized DB PC Trial & $\begin{array}{l}2 \mathrm{~g} \text { calcium/day or } \\
\text { placebo }\end{array}$ & $\begin{array}{l}30 \text { women ( } 28 \text { to } 32 \text { weeks of } \\
\text { gestation) }\end{array}$ & $\begin{array}{l}\text { Limited data shows reduction in the } \\
\text { risk of pre-eclampsia }\end{array}$ & Not Reported \\
\hline
\end{tabular}

\subsection{Physical Activity and Exercises}

It can be possibly believed that increased physical activities and exercise may help pregnant women in the prevention of developing pre-eclampsia as its benefits are many for non-pregnant people [43]. There are, however, also concerns that there may be adverse effects of exercise taken during pregnancy and hence the role of increased physical activity and exercise is controversial and not clear. Table 7 shows the summary of physical activities and exercise-related studies included in this review.

For inactive pregnant women, a stretching exercise may be more effective than walking in mitigating the risk of pre-eclampsia due to higher adherence and possible cardiac-physiologic effects [44]. However, the results do not deny the effects of walking exercise on risk of pre-eclampsia. In the light of this review, no firm conclusion can be drawn about recommending rest or increased activity to women, due to the insufficient evidence obtained in [42] [45]. However, further research is needed in different settings and trials to explain its role in the development and prevention of pre-eclampsia and its complications.

\subsection{Other Interventions}

Table 8 shows the summary of included studies related to miscellaneous interventions.

\subsubsection{Low Salt Diet}

The effects of salt consumption during pregnancy were assessed in a systematic review [46] with two trials involving 603 women. Both trials compared reduce dietary salt intake with normal diet. However, the review did not show any evidence of benefit for the mother or baby. Hence the salt consumption during pregnancy should remain a matter of personal choice.

\subsubsection{Chinese Herbal Medicines}

Proponents of traditional Chinese Medicine (TCM) believe that during pregnancy most of the blood of the mother flows to the placenta to provide the fetus with the required blood circulation and nutrition and as a result, other organs of 
Table 7. Summary of physical activities and exercise related studies included in this review.

\begin{tabular}{|c|c|c|c|c|c|}
\hline Ref. & Study Type & Intervention & Population/Sample Size & Results/Benefits & Adverse Effects \\
\hline [44] & $\begin{array}{l}\text { Randomized } \\
\text { Control Trial }\end{array}$ & $\begin{array}{l}\text { Physical Activity } \\
\text { and Exercise }\end{array}$ & $\begin{array}{l}124 \text { women }(<14 \text { weeks } \\
\text { Pregnancy) }\end{array}$ & $\begin{array}{l}\text { Stretching exercise may be more effective than } \\
\text { walking in reducing the risk of pre-eclampsia. }\end{array}$ & Not Reported \\
\hline [43] & $\begin{array}{l}\text { Systematic } \\
\text { Review }\end{array}$ & $\begin{array}{l}\text { Physical Activity } \\
\text { and Exercise }\end{array}$ & $\begin{array}{l}2 \text { small, good quality } \\
\text { trials with } 45 \text { women }\end{array}$ & Insufficient evidence for reliable conclusions & $\begin{array}{l}\text { Insufficient } \\
\text { evidence }\end{array}$ \\
\hline [45] & $\begin{array}{l}\text { Systematic } \\
\text { Review }\end{array}$ & $\begin{array}{l}\text { Physical Activity } \\
\text { and Exercise }\end{array}$ & $\begin{array}{l}2 \text { small, low quality trials } \\
\text { (106 women) }\end{array}$ & Insufficient evidence for reliable conclusions & $\begin{array}{l}\text { Insufficient } \\
\text { evidence }\end{array}$ \\
\hline
\end{tabular}

Table 8. Summary of other interventions related studies

\begin{tabular}{|c|c|c|c|c|c|}
\hline Ref. & Study Type & Intervention & Population/ Sample Size & Results/Benefits & Adverse Effects \\
\hline [46] & SR & Low Salt Diet & 2 Trials with 603 women & No Effect (Insufficient Data) & Not Reported \\
\hline [47] & SR & Chinese herbal medicines & $\begin{array}{l}\text { No trials suitable for } \\
\text { inclusion }\end{array}$ & Insufficient evidence & $\begin{array}{l}\text { Insufficient } \\
\text { evidence }\end{array}$ \\
\hline [49] & DB RCT & n-3 LCPUFA (fish oil) & $\begin{array}{l}2399 \text { Pregnant women } \\
\text { of }<21 \text { week pregnancy }\end{array}$ & $\begin{array}{l}\text { No meaningful effect on the risk } \\
\text { of pre-eclampsia }\end{array}$ & Not Reported \\
\hline [50] & SR & Garlic & 1 trial (100 women) & Insufficient evidence & Odour \\
\hline [51] & $\begin{array}{l}\text { Randomized DB } \\
\text { PC Trial }\end{array}$ & glyceryl trinitrate $5 \mathrm{mg}$ daily & $\begin{array}{l}40 \text { women ( } 24 \text { - } 26 \text { weeks } \\
\text { pregnancy) }\end{array}$ & $\begin{array}{l}\text { No reduction in pre-eclampsia, } \\
\text { preterm delivery or fetal growth } \\
\text { restriction }\end{array}$ & Not Reported \\
\hline [48] & SR & $\begin{array}{l}\text { Marine oil \& prostaglandin } \\
\text { precursor }\end{array}$ & 6 trials with 2783 women & $\begin{array}{l}\text { Not enough evidence to support } \\
\text { the routine use of marine oil, or } \\
\text { other prostagland in precursor }\end{array}$ & Not Reported \\
\hline [52] & SR & $\begin{array}{l}\text { Nitric oxide donors or pre- } \\
\text { cursors }\end{array}$ & 6 trials with 310 women & $\begin{array}{l}\text { Insufficient evidence to draw } \\
\text { reliable conclusions }\end{array}$ & $\begin{array}{l}\text { Headache with } \\
\text { little evidence }\end{array}$ \\
\hline [54] & SR & Plasma Volume Expansion & 3 trials with 61 women & $\begin{array}{l}\text { Insufficient evidence to draw } \\
\text { reliable conclusions }\end{array}$ & Not Reported \\
\hline [56] & SR & Cigarette smoking & 48 epidemiologic studies & $\begin{array}{l}\text { Smoking during pregnancy } \\
\text { reduces the risk of pre-eclampsia } \\
\text { by up to } 50 \% \text { with a } \\
\text { dose-response pattern }\end{array}$ & Not Reported \\
\hline [57] & SR & Low-dose dopamine & 1 trial (40 women) & Insufficient Evidence & Not Reported \\
\hline [58] & SR & progesterone & 4 trials ( 1445 women) & Insufficient Evidence & Not Reported \\
\hline [59] & SR & Diuretics & 5 studies (1836 women) & Insufficient Evidence & $\begin{array}{l}\text { Nausea, Vo- } \\
\text { miting }\end{array}$ \\
\hline [60] & $\begin{array}{l}\text { Randomized DB } \\
\text { PC Trial }\end{array}$ & Lycopene oral 2mg daily & $\begin{array}{l}159 \text { Women ( } 12 \text { to } 20 \text { weeks } \\
\text { of gestation) }\end{array}$ & $\begin{array}{l}\text { No significant difference be- } \\
\text { tween } \\
\text { the two groups in developing } \\
\text { pre-eclampsia }\end{array}$ & $\begin{array}{l}\text { Increased pre- } \\
\text { term labour }\end{array}$ \\
\hline [53] & $\begin{array}{l}\text { Randomized DB } \\
\text { PC Trial }\end{array}$ & $\begin{array}{l}\text { L-arginine plus antioxidant } \\
\text { vitamins }\end{array}$ & $\begin{array}{l}672 \text { pre-eclamptic women } \\
\text { (14 - } 32 \text { weeks pregnancy) }\end{array}$ & $\begin{array}{l}\text { Reduced the incidence of } \\
\text { pre-eclampsia. }\end{array}$ & Not Reported \\
\hline
\end{tabular}

the mother get weak [47]. The effectiveness of TCM in pre-eclampsia was assessed in a systematic review [47] in which the authors identified 45 studies but none could be classified as a randomized controlled trial. The usefulness of Chinese herbal medicines for treating pre-eclampsia hence remains unclear due to insufficient evidence. 


\subsubsection{Marine Oil Supplementation}

Population studies have shown that higher intakes of marine foods (seafood) during pregnancy are associated with higher infant birth weights and a low incidence of pre-eclampsia [48]. The Marine food contains fatty acids which are believed to be helpful in preventing the incidence of pre-eclampsia. However, there is insufficient evidence to support the routine use of marine food and oil during pregnancy in order to minimize the risk of pre-eclampsia and its related complications [48] [49].

\subsubsection{Garlic}

Similarly, there is insufficient evidence to recommend increased garlic intake for preventing pre-eclampsia and its complications during pregnancy as evident from a systematic review [50] with one included trial (100 women). Further large randomized trials evaluating the effects of garlic are needed before any recommendations can be made to guide clinical practice.

\subsubsection{Nitric Oxide}

Nitric oxide drugs (glycerol trinitrate) or their precursors (Arginine) relaxing the walls of the blood vessel and may play an effective role in the prevention of preeclampsia. However, there is insufficient evidence to draw reliable conclusions about whether nitric oxide drugs or their precursors prevent pre-eclampsia and its related complications [51] [52].

Although, one randomized, blinded, placebo-controlled clinical trial [53] show some evidence of a reduction in the incidence of pre-eclampsia. Participants in this trial were pregnant women with a history of a previous pregnancy pre-eclampsia. 222 women were allocated to the placebo group, 228 received Larginine plus antioxidant vitamins, and 222 received antioxidant vitamins alone. The incidence of pre-eclampsia was reduced significantly $(\mathrm{X} 2=19.41 ; \mathrm{P}<$ 0.001 ) in L-arginine plus antioxidant vitamins compared with placebo (absolute risk reduction 0.17 (95\% CI, 0.12 to 0.21 ). L-arginine plus antioxidant vitamins compared with antioxidant vitamins alone resulted in a significant effect $(\mathrm{P}=$ 0.004; absolute risk reduction $0.09,0.05$ to 0.14 ). Supplementation with Larginine plus antioxidant vitamins need to be further evaluated in a low-risk population in order for the firm conclusion to be drawn.

\subsubsection{Plasma Volume Expansion}

Blood plasma volume increases gradually in women during the second half of pregnancy and is reduced in women with pre-eclampsia [54]. It is possible that women with pre-eclampsia might benefit from expanded plasma volume if it were to increase blood circulation for the mother and baby. However, the results of a systematic review [54] are inconclusive about the effects of plasma volume expansion for the treatment of women with pre-eclampsia.

\subsubsection{Cigarette Smoking}

Cigarette smoking adversely affects every organ system [55]. However, very strangely, smoking during pregnancy has been associated with a reduction in the 
risk of pre-eclampsia in [56].

The relation between smoking and pre-eclampsia was studied in a review [56], conducted from 1959 to March 2006 with a total of 48 epidemiological studies. Overall, smoking during pregnancy reduces the risk of pre-eclampsia by up to $50 \%$ with a dose-response pattern. This result was consistent with all nulliparous and multiparas women, singleton and multifetal pregnancies, and in all cases of mild and severe pre-eclampsia. However, the underlying mechanisms and the exact ingredients in cigarette smoke that influence the risk of pre-eclampsia is unclear. However, given the other harmful effects of smoking, this cannot be generally considered a prevention method for pre-eclampsia. Further research and more epidemiological studies are needed to enhance our understanding of the disease and to clarify this puzzling relationship.

\subsubsection{Low-Dose Dopamine}

The role of low-dose dopamine in the management of pregnant women with severe pre-eclampsia was assessed in a systematic review in [57]. Only one Randomized placebo-controlled trial of six hours' duration, including 40 postpartum women, was found. However, it remained unclear whether low-dose dopamine therapy for pre-eclamptic women with oliguria is beneficial.

\subsubsection{Progesterone}

According to one theory the shortage of progesterone might be the cause of preeclampsia, hence it is believed that progesterone during pregnancy might help them to avoid pre-eclampsia. However, no reliable conclusions could be made about the effects of progesterone in preventing pre-eclampsia and its complications according to the result of a review in [58].

\subsubsection{Thiazide Diuretics}

Diuretic drugs result in reducing the blood pressure by excreting more urine and hence relaxing blood vessels. Due to these effects, it has been believed that Diuretic drugs might lower the risk of pre-eclampsia in pregnant women. However, the result drew in a systematic review [59] (5 studies involving 1,836 women), showed insufficient evidence to draw reliable conclusions about the effects of diuretics on prevention of pre-eclampsia and its related complications. The risk of nausea and vomiting was also increased, therefore the use of diuretics for the prevention of pre-eclampsia and its related complications cannot be suggested.

\subsubsection{Antioxidant Oral Lycopene}

A randomized double-blind placebo-controlled trial [60] with 159 primigravidas (similar physical and social parameters) was conducted in India to evaluate the efficacy of antioxidant lycopene in preventing pre-eclampsia. 77 women received $2 \mathrm{mg} /$ day oral lycopene until delivery. There was no significant difference in developing pre-eclampsia. The results confirm that lycopene is not effective in preventing pre-eclampsia in healthy primigravidas. Rather, they result in the incidence of the adverse effects of preterm labor and low birth weight babies. 


\section{Conclusions}

There are many medications and techniques that have been identified and assessed for its role in the prevention of pre-eclampsia and eclampsia. Magnesium sulfate so far has shown a great success in this regard and can be called as treatment of choice. It is more effective than diazepam, phenytoin, aspirin, calcium supplementation or lytic cocktail. However, despite the strong evidence, trials comparing alternative techniques are too small for reliable conclusions. There is insufficient evidence to show what the best dose and route of magnesium sulfate for women with pre-eclampsia or eclampsia are.

Similarly, the role of aspirin, calcium supplementation, and L-arginine plus antioxidant vitamins continues to be controversial. Its benefits and effectiveness range from small to moderate depending on the outcome. Further research is needed to assess which women are most likely to benefit. There is also insufficient evidence about whether to recommend rest or increased physical activity to women during pregnancy. Further research is highly desirable in different settings to explain its role in the development and prevention of pre-eclampsia and its complications.

There is evidence in the light of the included studies in this review as well as previous studies that supplementation with vitamins $\mathrm{C}$ and $\mathrm{E}$ did not reduce the risk of pre-eclampsia in both nulliparous and multiparous women. However, further research is needed to analyze the possibility that vitamin supplementation might be helpful in women with a low antioxidant status.

Another puzzling evidence we obtained from this review is that smoking during pregnancy reduces the risk of pre-eclampsia by up to $50 \%$ with a dose response pattern. This result was consistently found in nulliparous and multiparas, singleton and multifetal pregnancies for both mild and severe preeclampsia. Current literature does not give us a clear explanation for this supportive effect of smoking in pregnant women. However, considering its harmful effects, smoking cannot be considered as a prevention method for pre-eclampsia. Further research and more epidemiological studies are needed to enhance our understanding of the disease and to clarify this puzzling relationship.

Moreover, there are no systematic reviews and control trails based on immediate delivery of the baby (the definitive treatment for pre-eclampsia and eclampsia) and another important standard-of-care treatment (non-diuretic anti-hypertensives).

We also recommend further research into assessing the role and importance of current and new technologies and techniques in the reduction of pre-eclampsia and eclampsia. All nurses or midwives should know the evidence about the prevention and treatment of pre-eclampsia and eclampsia to identify the nursing care that is essential to guide the pregnant woman and family and prevent adverse events related to the use of preferred techniques and medications.

\section{Acknowledgements}

We wish to thank The World Academy of Sciences (TWAS), Italy and the Na- 
tional Council for Scientific and Technological Development (CNPq), Brazil for their financial assistance.

\section{References}

[1] Duley, L., Henderson-Smart, D.J. and Walker, G.J.A. (2009) Interventions for Treating Pre-Eclampsia and Its Consequences: Generic Protocol. The Cochrane Library, Hoboken.

[2] World Health Organization, et al. (2011) Who Recommendations for Prevention and Treatment of Pre-Eclampsia and Eclampsia. World Health Organization, Geneva.

[3] Khan, K.S., Wojdyla, D., Say, L., Gu“lmezoglu, A.M. and Van Look, P.F.A. (2006) Who Analysis of Causes of Maternal Death: A Systematic Review. The Lancet, 367, 1066-1074. https://doi.org/10.1016/S0140-6736(06)68397-9

[4] WHO (2016) WHO Maternal Mortality, Geneva.

[5] Myles, M.F. (1993) Myles Textbook for Midwives, Volume 10. 12th Edition, Churchill Livingstone, Edinburgh.

[6] Ghulmiyyah, L. and Sibai, B. (2012) Maternal Mortality from Preeclampsia/Eclampsia. Seminars in Perinatology, 36, 56-59. https://doi.org/10.1053/j.semperi.2011.09.011

[7] Duley, L. (2009) The Global Impact of Pre-Eclampsia and Eclampsia. Seminars in Perinatology, 33, 130-137. https://doi.org/10.1053/j.semperi.2009.02.010

[8] Roberts, C.L., Ford, J.B., Algert, C.S., Antonsen, S., Chalmers, J., Cnattingius, S., Gokhale, M., Kotelchuck, M., Melve, K.K., Langridge, A., et al. (2011) Population-Based Trends in Pregnancy Hypertension and Pre-Eclampsia: An International Comparative Study. BMJ Open, 1, e000101. https://doi.org/10.1136/bmjopen-2011-000101

[9] Moher, D., Liberati, A., Tetzlaff, J., Altman, D.G. and The PRISMA Group (2009) Preferred Reporting Items for Systematic Reviews and Meta-Analyses: The Prisma Statement. PLoS Med, 6, e1000097. https://doi.org/10.1371/journal.pmed.1000097

[10] Niromanesh, S., Laghaii, S. and Mosavi-Jarrahi, A. (2001) Supplementary Calcium in Prevention of Pre-Eclampsia. International Journal of Gynecology \& Obstetrics, 74, 17-21. https://doi.org/10.1016/S0020-7292(01)00374-5

[11] Duley, L., Henderson-Smart, D.J., Meher, S. and King, J.F. (2007) Antiplatelet Agents for Preventing Pre-Eclampsia and Its Complications (Review). Cochrane Database of Systematic Reviews, No. 2, CD004659.

[12] Belfort, M.A., Anthony, J., Saade, G.R. and Allen, J.C. (2003) A Comparison of Magnesium Sulfate and Nimodipine for the Prevention of Eclampsia. New England Journal of Medicine, 348, 304-311. https://doi.org/10.1056/NEJMoa021180

[13] Duley, L., Gulmezoglu, A.M. and Chou, D. (2010) Magnesium Sulphate versus Lytic Cocktail for Eclampsia. The Cochrane Database of Systematic Reviews, No. 9, CD002960.

[14] Duley, L., Gulmezoglu, A.M., Henderson-Smart, D.J. and Chou, D. (2010) Magnesium Sulphate and Other Anticonvulsants for Women with Pre-Eclampsia. Cochrane Database of Systematic Reviews, No. 11, CD000025.

[15] Sibai, B.M. (1990) Magnesium Sulfate Is the Ideal Anticonvulsant in Preeclampsia-Eclampsia. American Journal of Obstetrics and Gynecology, 162, 1141-1145. https://doi.org/10.1016/0002-9378(90)90002-O 
[16] Coetzee, E.J., Dommisse, J. and Anthony, J. (1998) A Randomised Controlled Trial of Intravenous Magnesium Sulphate versus Placebo in the Management of Women with Severe Pre-Eclampsia. BJOG: An International Journal of Obstetrics \& Gynaecology, 105, 300-303. https://doi.org/10.1111/j.1471-0528.1998.tb10090.x

[17] The Eclampsia Trial Collaborative Group (1995) Which Anticonvulsant for Women with Eclampsia? Evidence from the Collaborative Eclampsia Trial. The Lancet, 345, 1455-1463. https://doi.org/10.1016/S0140-6736(95)91034-4

[18] Chowdhury, J.R., Chaudhuri, S., Bhattacharyya, N., Biswas, P.K. and Panpalia, M. (2009) Comparison of Intramuscular Magnesium Sulfate with Low Dose Intravenous Magnesium Sulfate Regimen for Treatment of Eclampsia. Journal of Obstetrics and Gynaecology Research, 35, 119-125. https://doi.org/10.1111/j.1447-0756.2008.00842.x

[19] Rantonen, T., Kaapa, P., Gronlund, J., Ekblad, U., Helenius, H., Kero, P. and Valimaki, I. (2001) Maternal Magnesium Sulfate Treatment Is Associated with Reduced Brain-Blood Flow Perfusion in Preterm Infants. Critical Care Medicine, 29, 1460-1465. https://doi.org/10.1097/00003246-200107000-00026

[20] Villa, P.M., Kajantie, E., Raikkonen, K., Pesonen, A.-K., Hamalainen, E., Vainio, M., Taipale, P. and Laivuori, H. (2013) Aspirin in the Prevention of Preeclampsia in High-Risk Women: A Randomised Placebo-Controlled Predo Trial and a $\mathrm{Me}$ ta-Analysis of Randomised Trials. BJOG: An International Journal of Obstetrics \& Gynaecology, 120, 64-74. https://doi.org/10.1111/j.1471-0528.2012.03493.x

[21] Rotchell, Y.E., Cruickshank, J.K., Phillips Gay, M., Griffiths, J., Stewart, A., Farrell, B., Ayers, S., Hennis, A., Grant, A., Duley, L., et al. (1998) Barbados Low Dose Aspirin Study in Pregnancy (Blasp, a Randomised Trial for the Prevention of Pre-Eclampsia and Its Complications. BJOG: An International Journal of Obstetrics \& Gynaecology, 105, 286-292. https://doi.org/10.1111/j.1471-0528.1998.tb10088.x

[22] Haapsamo, M., Martikainen, H., Tinkanen, H., Heinonen, S., Nuojua-Huttunen, S. and Rasanen, J. (2010) Low-Dose Aspirin Therapy and Hypertensive Pregnancy Complications in Unselected IVF and ICSI Patients: A Randomized, Placebo-Controlled, Double-Blind Study. Human Reproduction, 25, 2972-2977. https://doi.org/10.1093/humrep/deq286

[23] Subtil, D., Goeusse, P., Puech, F., Lequien, P., Biausque, S., Breart, G., Uzan, S., Marquis, P., Parmentier, D. and Churlet, A. (2003) Aspirin (100 mg) Used for Prevention of Pre-Eclampsia in Nulliparous Women: The Essai Régional Aspirine Mère-Enfant Study (Part 1). BJOG: An International Journal of Obstetrics \& GYnaecology, 110, 475-484.

[24] Yu, C.K.H., Papageorghiou, A.T., Parra, M., Palma Dias, R. and Nicolaides, K.H. (2003) Randomized Controlled Trial Using Low-Dose Aspirin in the Prevention of Pre-Eclampsia in Women with Abnormal Uterine Artery Doppler at 23 Weeks' Gestation. Ultrasound in Obstetrics \& Gynecology, 22, 233-239.

https://doi.org/10.1002/uog.218

[25] Caritis, S., Sibai, B., Hauth, J., Lindheimer, M.D., Klebanoff, M., Thom, E., Vandorsten, P., Landon, M., Paul, R., Miodovnik, M., et al. (1999) Low-Dose Aspirin to Prevent Preeclampsia in Women at High Risk. Survey of Anesthesiology, 43, 24. https://doi.org/10.1097/00132586-199902000-00025

[26] Livingston, J.C., Livingston, L.W., Ramsey, R., Mabie, B.C. and Sibai, B.M. (2003) Magnesium Sulfate in Women with Mild Preeclampsia: A Randomized Controlled Trial. Obstetrics \& Gynecology, 101, 217-220.

[27] Duley, L., Matar, H.E., Almerie, M.Q. and Hall, D.R. (2010) Alternative Magnesium Sulphate Regimens for Women with Preeclampsia and Eclampsia. The Cochrane 
Database of Systematic Reviews, No. 8, CD007388.

[28] Chiaffarino, F., Parazzini, F., Paladini, D., Acaia, B., Ossola, W., Marozio, L., Facchinetti, F. and Del Giudice, A. (2004) A Small Randomised Trial of Low-Dose Aspirin in Women at High Risk of Preeclampsia. European Journal of Obstetrics \& Gynecology and Reproductive Biology, 112, 142-144. https://doi.org/10.1016/S0301-2115(03)00269-0

[29] Sibai, B.M., Caritis, S.N., Thom, E., Klebanoff, M., McNellis, D., Rocco, L., Paul, R.H., Romero, R., Witter, F., Rosen, M., et al. (1993) Prevention of Preeclampsia with Low-Dose Aspirin in Healthy, Nulliparous Pregnant Women. New England Journal of Medicine, 329, 1213-1218. https://doi.org/10.1056/NEJM199310213291701

[30] Xu, H., Perez-Cuevas, R., Xiong, X., Reyes, H., Roy, C., Julien, P., Smith, G., von Dadelszen, P., Leduc, L., Audibert, F., et al. (2010) An International Trial of Antioxidants in the Prevention of Preeclampsia (Intapp). American Journal of Obstetrics and Gynecology, 202, 239.e1-239.e10. https://doi.org/10.1016/j.ajog.2010.01.050

[31] Gulmezoglu, A.M., Hofmeyr, G.J. and Oosthuisen, M.M.J. (1997) Antioxidants in the Treatment of Severe Pre-Eclampsia: An Explanatory Randomised Controlled Trial. British Journal of Obstetrics and Gynaecology, 104, 689-696. https://doi.org/10.1111/j.1471-0528.1997.tb11979.x

[32] Villar, J., Purwar, M., Merialdi, M., Zavaleta, N., Anthony, J., De Greeff, A., Poston, L., Shennan, A., et al. (2009) World Health Organisation Multicentre Randomised Trial of Supplementation with Vitamins c and e among Pregnant Women at High Risk for Pre-Eclampsia in Populations of Low Nutritional Status from Developing Countries. BJOG: An International Journal of Obstetrics \& Gynaecology, 116, 780-788. https://doi.org/10.1111/j.1471-0528.2009.02158.x

[33] Rumbold, A., Duley, L., Crowther, C.A. and Haslam, R.R. (2008) Antioxidants for Preventing Pre-Eclampsia. The Cochrane Database of Systematic Reviews, No. 4, CD004227.

[34] McCance, D.R., Holmes, V.A., Maresh, M.J.A., Patterson, C.C., Walker, J.D., Pearson, D.W.M., Young, I.S., et al. (2010) Vitamins c and e for Prevention of Pre-Eclampsia in Women with Type 1 Diabetes (Dapit, a Randomised Placebo-Controlled Trial. The Lancet, 376, 259-266. https://doi.org/10.1016/S0140-6736(10)60630-7

[35] Rumbold, A.R., Crowther, C.A., Haslam, R.R., Dekker, G.A. and Robinson, J.S. (2006) Vitamins c and e and the Risks of Preeclampsia and Perinatal Complications. New England Journal of Medicine, 354, 1796-1806.

[36] Poston, L., Briley, A.L., Seed, P.T., Kelly, F.J., Shennan, A.H., et al. (2006) Vitamin c and vitamin e in Pregnant Women at Risk for Pre-Eclampsia (Vip Trial, Randomised Placebocontrolled Trial. The Lancet, 367, 1145-1154. https://doi.org/10.1016/S0140-6736(06)68433-X

[37] Roberts, J.M., Myatt, L., Spong, C.Y., Thom, E.A., Hauth, J.C., Leveno, K.J., Pearson, G.D., Wapner, R.J., Varner, M.W., Thorp, J.M., et al. (2010) Vitamins c and e to Prevent Complications of Pregnancy-Associated Hypertension. New England Journal of Medicine, 362, 1282-1291. https://doi.org/10.1056/NEJMoa0908056

[38] Spinnato, J.A., Freire, S., Pinto e Silva, J.L., Rudge, M.V.C., Martins-Costa, S., Koch, M.A., Goco, N., de Barros Santos, C., Cecatti, J.G., Costa, R., et al. (2007) Antioxidant Therapy to Prevent Preeclampsia: A Randomized Controlled Trial. Obstetrics \& Gynecology, 110, 1311-1318. https://doi.org/10.1097/01.AOG.0000289576.43441.1f 
[39] Villar, J. and Belizan, J.M. (2000) Same Nutrient, Different Hypotheses: Disparities in Trials of Calcium Supplementation during Pregnancy. The American Journal of Clinical Nutrition, 71, 1375s-1379s.

[40] Villar, J., Abdel-Aleem, H., Merialdi, M., Mathai, M., Ali, M.M., Zavaleta, N., Purwar, M., Hofmeyr, J., Campodonico, L., Landoulsi, S., et al. (2006) World Health Organization Randomized Trial of Calcium Supplementation among Low Calcium Intake Pregnant Women. American Journal of Obstetrics and Gynecology, 194, 639-649. https://doi.org/10.1016/j.ajog.2006.01.068

[41] Levine, R.J., Hauth, J.C., Curet, L.B., Sibai, B.M., Catalano, P.M., Morris, C.D., DerSimonian, R., Esterlitz, J.R., Raymond, E.G., Bild, D.E., et al. (1997) Trial of Calcium to Prevent Preeclampsia. New England Journal of Medicine, 337, 69-77. https://doi.org/10.1056/NEJM199707103370201

[42] Hofmeyr, G.J., Duley, L. and Atallah, A. (2007) Dietary Calcium Supplementation for Prevention of Pre-Eclampsia and Related Problems: A Systematic Review and Commentary. BJOG: An International Journal of Obstetrics \& Gynaecology, 114, 933-943. https://doi.org/10.1111/j.1471-0528.2007.01389.x

[43] Meher, S. and Duley, L. (2006) Exercise or Other Physical Activity for Preventing Pre-Eclampsia and Its Complications. The Cochrane Database of Systematic Reviews, No. 2, CD005942.

[44] Yeo, S. (2009) Adherence to Walking or Stretching, and Risk of Preeclampsia in Sedentary Pregnant Women. Research in Nursing \& Health, 32, 379-390. https://doi.org/10.1002/nur.20328

[45] Meher, S. and Duley, L. (2006) Rest during Pregnancy for Preventing Preeclampsia and Its Complications in Women with Normal Blood Pressure. The Cochrane Database of Systematic Reviews, No. 2, CD005939.

[46] Duley, L., Henderson-Smart, D.J. and Meher, S. (2005) Altered Dietary Salt for Preventing Pre-Eclampsia, and Its Complications. The Cochrane Database of Systematic Reviews, No. 4, CD005548.

[47] Li, W., Tang, L., Wu, T., Zhang, J., Liu, G.J. and Zhou, L. (2006) Chinese Herbal Medicines for Treating Pre-Eclampsia. The Cochrane Database of Systematic Reviews, No. 2, CD005126.

[48] Makrides, M., Duley, L. and Olsen, S.F. (2006) Marine Oil, and Other Prostaglandin Precursor, Supplementation for Pregnancy Uncomplicated by Pre-Eclampsia or Intrauterine Growth Restriction. The Cochrane Database of Systematic Reviews, No. 3, CD003402.

[49] Zhou, S.J., Yelland, L., McPhee, A.J., Quinlivan, J., Gibson, R.A. and Makrides, M. (2012) Fish-Oil Supplementation in Pregnancy Does Not Reduce the Risk of Gestational Diabetes or Preeclampsia. The American Journal of Clinical Nutrition, 95, 1378-1384. https://doi.org/10.3945/ajcn.111.033217

[50] Meher, S. and Duley, L. (2006) Garlic for Preventing Pre-Eclampsia and Its Complications. The Cochrane Database of Systematic Reviews, No. 3, CD006065.

[51] Lees, C., Valensise, H., Black, R., Harrington, K., Byiers, S., Romanini, C. and Campbell, S. (1998) The Efficacy and Fetal-Maternal Cardiovascular Effects of Transdermal Glyceryl Trinitrate in the Prophylaxis of Pre-Eclampsia and Its Complications: A Randomized Double-Blind Placebo-Controlled Trial. Ultrasound in Obstetrics \& Gynecology, 12, 334-338. https://doi.org/10.1046/j.1469-0705.1998.12050334.x

[52] Meher, S. and Duley, L. (2007) Nitric Oxide for Preventing Pre-Eclampsia and Its Complications. The Cochrane Database of Systematic Reviews, No. 2, CD006490. 
[53] Vadillo-Ortega, F., Perichart-Perera, O., Espino, S., Avila-Vergara, M.A., Ibarra, I., Ahued, R., Godines, M., Parry, S., Macones, G., Strauss, J.F., et al. (2011) Effect of Supplementation during Pregnancy with 1-Arginine and Antioxidant Vitamins in Medical Food on Pre-Eclampsia in High Risk Population: Randomised Controlled Trial. BMJ, 342, d2901.

[54] Duley, L., Williams, J. and Henderson-Smart, D.J. (2000) Plasma Volume Expansion for Treatment of Women with Pre-Eclampsia. The Cochrane Database of Systematic Reviews, No. 2, CD001805.

[55] Shea, A.K. and Steiner, M. (2008) Cigarette Smoking during Pregnancy. Nicotine \& Tobacco Research, 10, 267-278. https://doi.org/10.1080/14622200701825908

[56] England, L. and Zhang, J. (2007) Smoking and Risk of Preeclampsia: A Systematic Review. Frontiers in Bioscience, No. 12, 2471-2483.

[57] Wilhelm Steyn, D. and Steyn, P. (2007) Low-Dose Dopamine for Women with Severe Pre-Eclampsia. The Cochrane Database of Systematic Reviews, No. 1, CD003515.

[58] Meher, S. and Duley, L. (2009) Progesterone for Preventing Pre-Eclampsia and Its Complications.

[59] Churchill, D., Beevers, G.D.G., Meher, S. and Rhodes, C. (2007) Diuretics for Preventing Pre-Eclampsia. The Cochrane Database of Systematic Reviews, No. 1, CD004451.

[60] Banerjee, S., Jeyaseelan, S. and Guleria, R. (2009) Trial of Lycopene to Prevent Pre-Eclampsia in Healthy Primigravidas: Results Show Some Adverse Effects. Journal of Obstetrics and Gynaecology Research, 35, 477-482.

https://doi.org/10.1111/j.1447-0756.2008.00983.x 